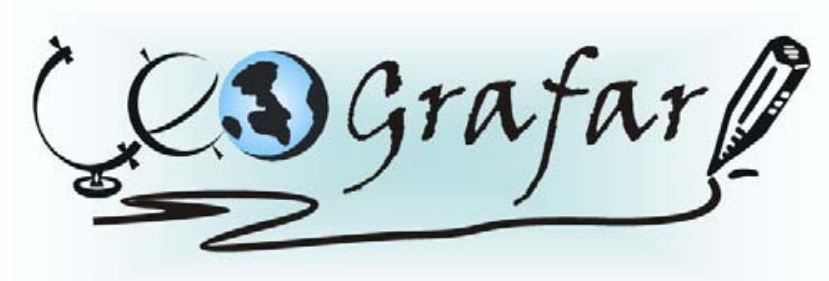

Revista Eletrônica do Programa de Pós-Graduação em Geografla - UFPR

\title{
INFLUÊNCIAS ANTRÓPICAS NO REMANESCENTE DA FLORESTA ATLÂNTICA NA ÁREA DE PROTEÇÃO AMBIENTAL DE GUARATUBA, PARANÁ
}

\author{
CLAUDINEI TABORDA DA SILVEIRA ${ }^{1}$ CHISATO OKA-FIORI ${ }^{2}$
}

\section{RESUMO}

A Área de Proteção Ambiental (APA) de Guaratuba, situada no estado do Paraná, é uma unidade de conservação de gestão estadual, que representa um significativo remanescente da floresta atlântica, sendo atualmente cenário de conflitos e transformações. Tais conflitos estão associados a diferentes interesses por parte de seus ocupantes, já que essa área é formada também por propriedades particulares, com distintas formas de uso do solo. Representa um cenário de transformações por sua localização geográfica, pois a leste esta a orla litorânea com crescente desenvolvimento ao turismo e lazer acarretando forte especulação imobiliária, e a oeste sua proximidade com Região Metropolitana de Curitiba, com grande adensamento demográfico e em fase de expansão por seus eixos metropolitanos. Assim, aqui são apresentadas e discutidas as diferentes influências antrópicas aos remanescentes florestais, bem como seus principais problemas de degradação ambiental.

Palavras Chave: APA de Guaratuba, influências antrópicas, floresta atlântica

\section{INFLUENCES ANTROPICS IN THE REMAINDER OF THE ATLANTIC FOREST IN THE AREA OF AMBIENT PROTECTION OF GUARATUBA, PARANÁ}

\begin{abstract}
The Area of Ambient Protection (APA) of Guaratuba, situated in the state of the Paraná, is a unit of conservation of state management, that represents a significant remainder of the Atlantic forest, being currently scene of conflicts and transformations. Such conflicts are associated with the different interests on the part of its occupants, as this area is also formed by particular properties, with distinct forms of use of the ground. It represents a scene of transformations for its geographic localization, by the east there is the coast with increasing development of the tourism and leisure causing strong real estate speculation, and by the west its proximity with Metropolitan Region of Curitiba, with great demographic increase and in phase of expansion in its metropolitans axis. Thus, the different antropics influences to the forest remainders are here presented and discussed, as well the main problems of ambiental degradation.
\end{abstract}

KEY WORDS: APA of Guaratuba, antropics influences, Atlantic forest

\footnotetext{
${ }^{1}$ Doutorando em Geografia pela Universidade Federal do Paraná, e-mail: claudineits@pop.com.br

${ }^{2}$ Professora doutora do Departamento de Geografia da Universidade Federal do Paraná, chisato@ufpr.br
} 


\section{INTRODUÇÃO}

A porção oriental do Paraná é a região com maior índice de cobertura florestal do estado, cujos aspectos fisiográficos associados the conferem uma paisagem impar. Situada na parte sul dessa região está a APA de Guaratuba, que compõe um cenário natural bastante preservado, abrigando grande parte dos remanescentes da Floresta Atlântica paranaense. Possuí uma vasta extensão territorial, cuja área de $1.995,86 \mathrm{~km}^{2}$ equivale aproximadamente $1 \%$ do território do estado, representando um dos importantes redutos ecológicos do Paraná. Sua grande importância ecológica se deve também pela diversidade da fauna e flora, associada à beleza natural das elevadas encostas montanhosas que compõe a Serra do Mar.

A Área de Proteção Ambiental (APA) de Guaratuba, que corresponde à área de estudo, está localizada nos municípios de Guaratuba, Matinhos, Paranaguá, Tijucas do Sul e São José dos Pinhais (figura 1), entre as coordenadas de latitudes $25^{\circ} 32^{\prime} 41^{\prime \prime}$ e $26^{\circ} 00^{\prime} 29^{\prime \prime}$ ' sul e longitudes $49^{\circ} 08^{\prime} 22^{\prime \prime}$ e $48^{\circ} 32^{\prime} 18^{\prime \prime}$ ' oeste.

É uma Unidade de Conservação (UC) de gestão estadual, com regulamentações legais permitem o uso e posse particular de suas terras, desde que sejam respeitadas as restrições ambientais vigentes. Sua localização geográfica confere-lhe um atenuante de preocupação, pois está situada entre dois cenários de grandes transformações antropogênicas, à leste a orla litorânea com crescente desenvolvimento ao turismo e lazer, com forte especulação imobiliária; e à oeste proximidade com Região Metropolitana de Curitiba (RMC), com grande adensamento demográfico e em fase de expansão por seus eixos metropolitanos.

A fragilidade ambiental dessa área já foi apontado nos estudos de Silveira (2005), que avaliou as características físico-naturais da área correlacionando-as com o uso e cobertura, apontando áreas hierarquizadas de acordo com suas características de instabilidade. Também, Bigarella et al (1978), desde a década de 1970 tem se preocupado com questões relativas à atuação antrópica na região costeira, apresentando considerações quanto à fragilidade e problemas encontrados na Serra do Mar, principalmente com os desmatamentos, apontando como um problema de segurança ambiental e nacional, ressaltando que erro nas previsões de uso pode desencadear conseqüências desastrosas.

Portanto, visa-se abordar no escopo desse trabalho as influências antrópicas no remanescente da Floresta Atântica que estão inseridas na unidade territorial da APA de Guaratuba, mostrando seus reflexos na paisagem, também apresentar e caracterizar a exuberante cobertura vegetal que ainda resta na região. 
FIGURA 1 - MAPA ILUSTRATIVO DA LOCALIZAÇÃO DA APA DE GUARATUBA

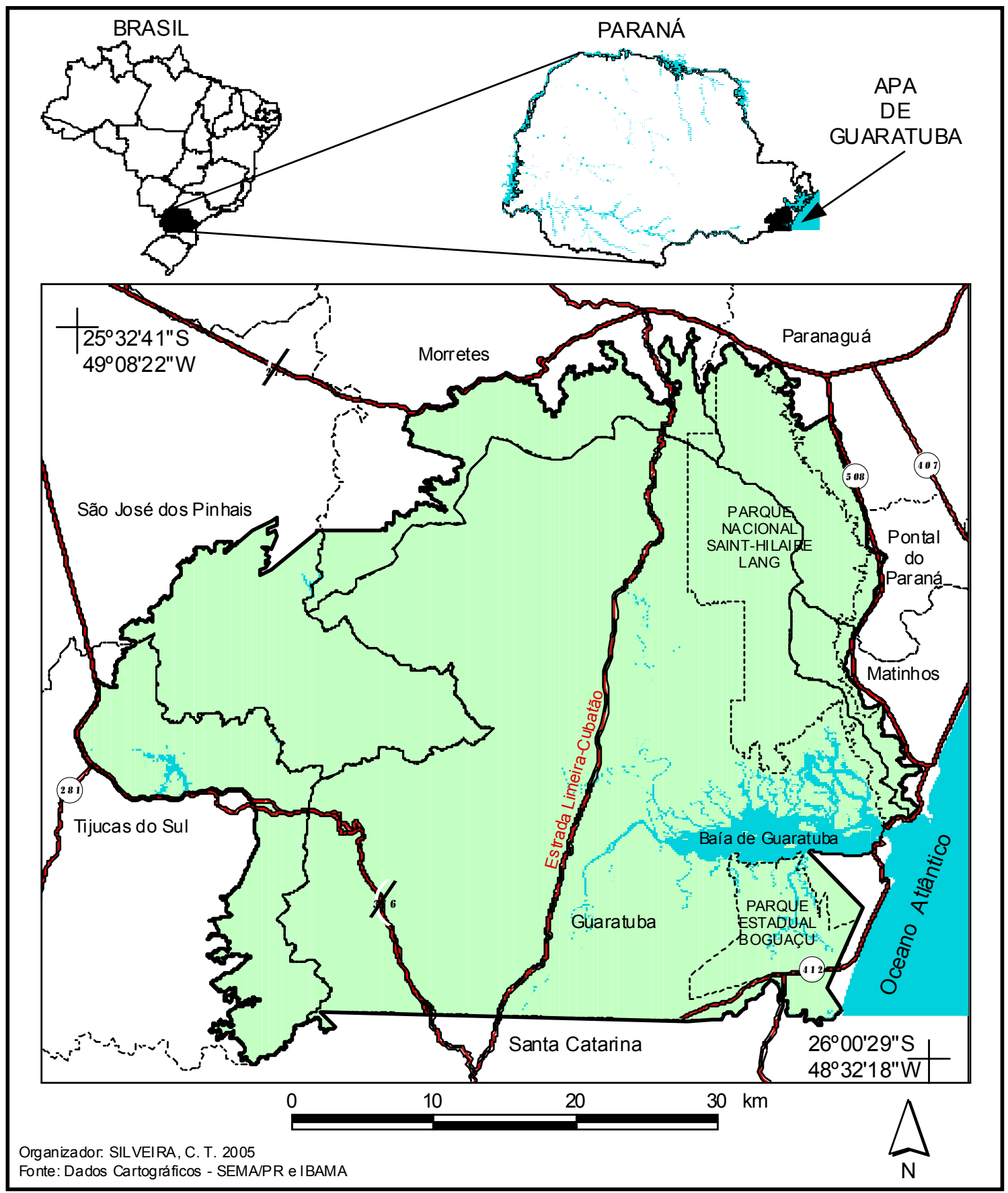

\section{MATERIAIS E MÉTODO}

A base de informação cartográfica utilizada foram cartas de vegetação na escala 1:50.000 e imagem de satélite Landsat7 TM+. Foi possível elaborar um mapa de Uso e Cobertura do Solo da área de estudo. Para um melhor detalhamento da cobertura vegetal e mais precisa identificação dos pontos de degradação foram realizados levantamentos de campo, onde foram percorridas todas as estradas trafegáveis, fazendo-se anotação das coordenadas com uso de um aparelho GPS e as descrições referentes a vários locais de parada (figura 2). 


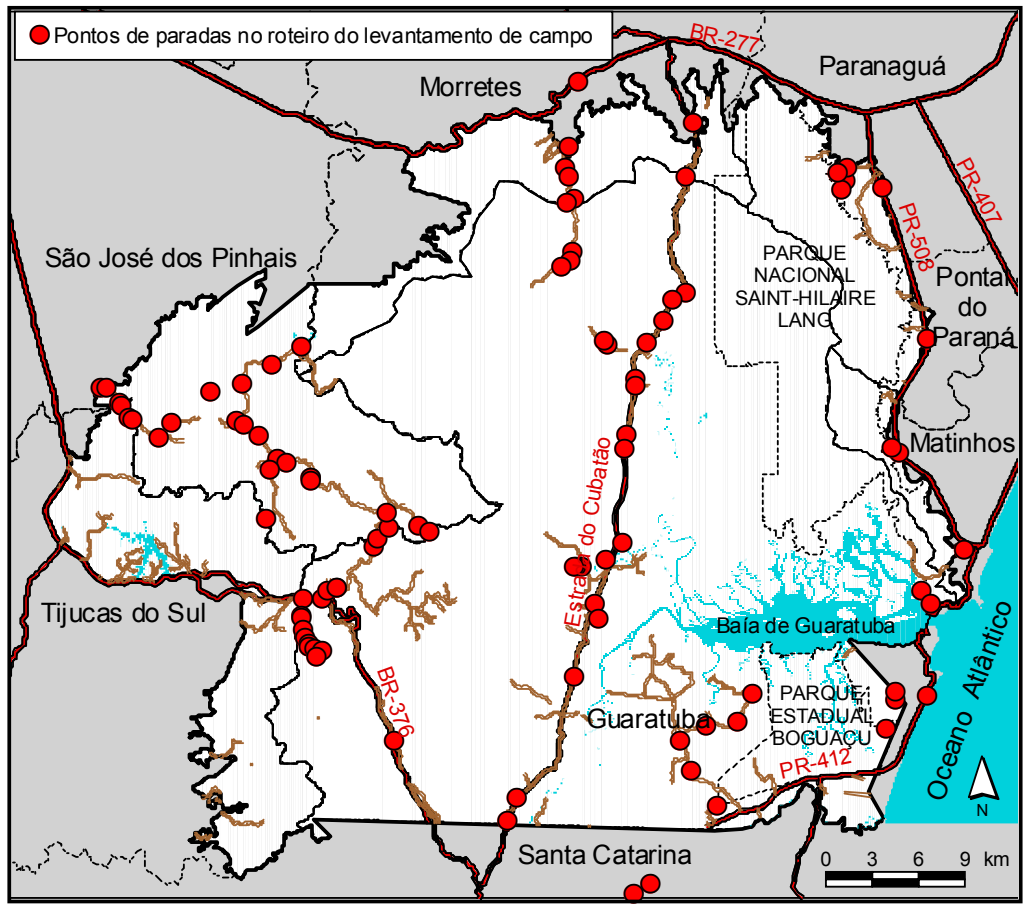

\section{CONCEITUAÇÃO LEGAL DE ÁREA DE PROTEÇÃO AMBIENTAL - APA}

No Brasil, conforme o Sistema Nacional de Unidades de Conservação - SNUC, Lei Federal $n^{\circ}$ 9.985, de 18 de julho de 2000, as Unidades de Conservação (UC's) são entendidas como sendo "o espaço territorial e seus recursos ambientais, incluindo as águas jurisdicionais com características naturais relevantes, legalmente instituído pelo poder público, com objetivos de conservação e limites definidos, sob regime especial de administração, ao qual se aplicam garantias adequadas de proteção". As Unidades de Conservação dividem-se em dois grupos: a) Unidades de Proteção Integral, que têm como objetivo básico preservar a natureza, admitindo apenas o uso indireto dos seus recursos naturais. Constituídas em cinco categorias de UC's: Estação Ecológica; Reserva Biológica; Parque Nacional; Monumento Natural e; Refúgio da Vida silvestre. b) Unidades de Uso Sustentável, que têm como objetivo compatibilizar a conservação da natureza com o uso sustentável de parcela dos seus recursos naturais. Organizadas em sete categorias de UC's: Área de Proteção Ambiental; Área de Relevante Interesse Ecológico; Floresta Nacional; Reserva Extrativista; Reserva da Fauna; Reserva de Desenvolvimento Sustentável e; Reserva Particular do Patrimônio Natural.

Área de Proteção Ambiental, conforme consta no Artigo 15 da Lei 9985, é uma área em geral extensa, com certo grau de ocupação humana, dotada de atributos abióticos, bióticos, estéticos ou culturais especialmente importantes para a qualidade de vida e o bem estar das populações humanas, e tem como objetivos básicos proteger à diversidade biológica, disciplinar o processo de ocupação e assegurar a sustentabilidade do uso dos recursos naturais. Complementa, ainda, o Artigo 15 com os seguintes parágrafos: $1^{\circ}$ ) a Área de Proteção Ambiental é constituída por terras pública ou privada; $2^{\circ}$ ) respeitados os limites constitucionais, podem ser estabelecidas normas e restrições para a utilização de uma 
propriedade privada localizada em uma Área de Proteção Ambiental; $3^{\circ}$ ) as condições para a realização de pesquisa científica e visitação pública nas áreas sob domínio público serão estabelecidas pelo órgão gestor da unidade; $4^{\circ}$ ) nas áreas sob propriedade privada, cabe ao proprietário estabelecer as condições para pesquisa e visitação pelo poder público, observando as exigências e restrições legais.

As unidades de conservação brasileiras de categoria APA podem ser de gestão dos municípios, estados ou da união federal. A APA de Guaratuba é de gestão do estado do Paraná, criada pelo decreto n ${ }^{\circ} 1.234$ em 27 de março de 1992.

\section{CONFIGURAÇÃO DO CENÁRIO DA APA DE GUARATURA}

Num dos pioneiros e mais clássicos trabalhos que tratam da geografia física do Paraná, Maack (1981) dividiu o Estado em cinco grandes zonas de paisagem natural. Dessas, três fazem parte da área de estudo: a Planície do Litoral Paranaense, a Serra do Mar e o Primeiro Planalto Paranaense.

Nesse contexto de inserção a APA de Guaratuba é composta por um mosaico de ambientes que abrange o relevo íngreme da Serra do Mar, com escarpas marcadas por paredões rochosos de forte declividade e drenagens em vales profundos, encaixados e estreitos; a planície litorânea com relevo muito suave, composto por planícies aluviais fluviais, com contribuições marinhas, situado na porção leste; regiões de planaltos, à oeste, com relevo constituído por colinas alongadas. Na imagem ilustrativa (figura 3) pode ser observado um panorama em perspectiva tridimensional da área de estudo.

\section{FIGURA 3 - IMAGEM EM PERSPECTIVA TRIDIMENSIONAL DA APA DE GUARATUBA}

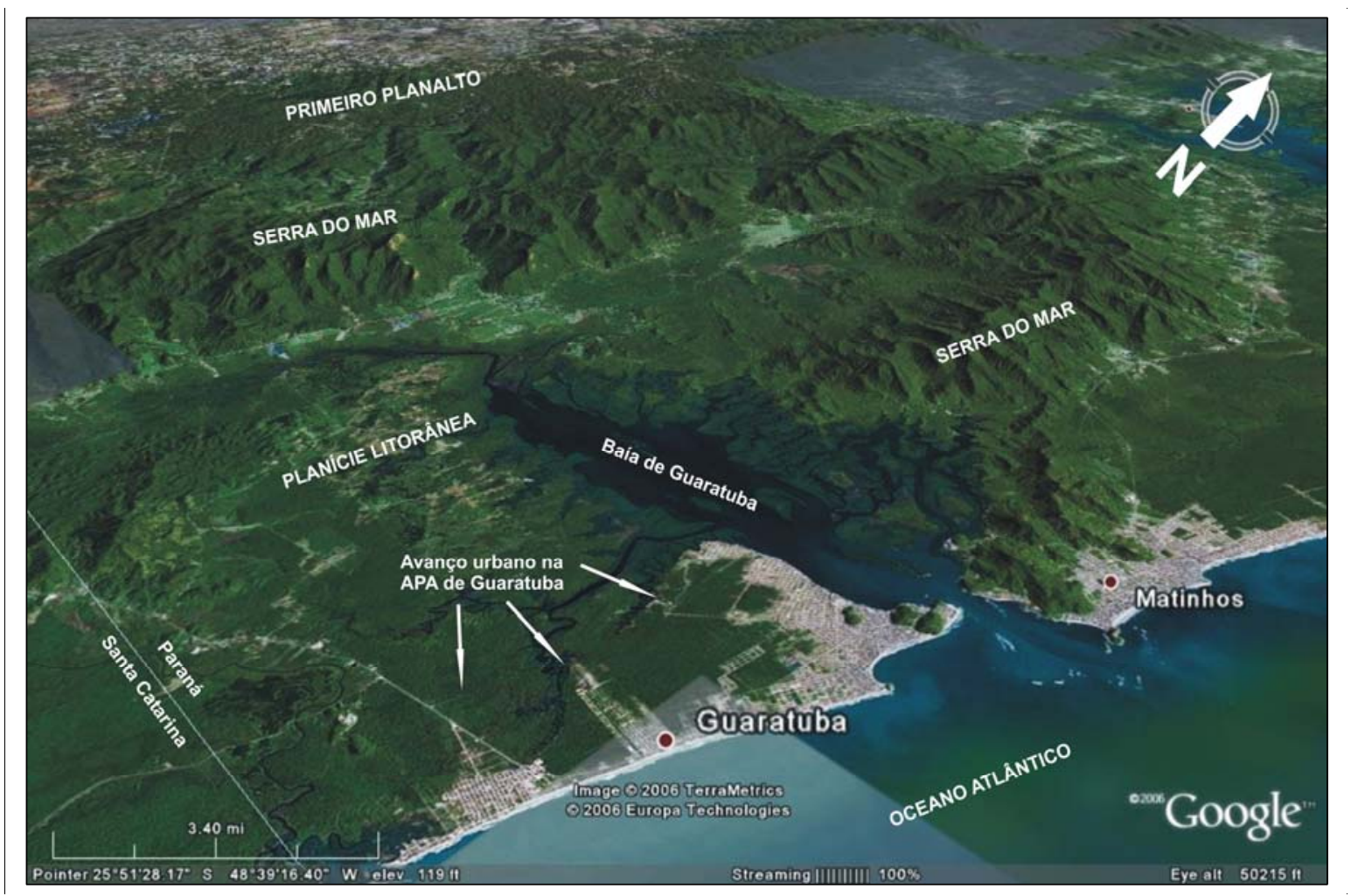

FONTE: GOOGLE EARTH, acesso em 2006 
Possuí também um ambiente natural bastante preservado, composto por áreas remanescentes da Floresta Atlântica, cuja extensão territorial é bastante representativa, principalmente quando comparado às demais regiões do Paraná nas quais restou muito pouco da vegetação original.

Segundo o Atlas de Vegetação do Estado do Paraná, elaborado pela SEMA (2002), ao tratar do estágio atual de conservação da vegetação no Paraná, apontou que atualmente a região dos planaltos do interior do estado se caracterizam por uma vegetação altamente degradada, composta por pequenos remanescentes fragmentados e em diferentes estágios sucessionais. A maior perda de floresta é verificada nas regiões oeste, noroeste e norte do estado, no domínio da Floresta Estacional Semidecidual, onde se concentra hoje a maior parte dos empreendimentos agropecuários. O Centro-sul do estado, região da Floresta Ombrófila Mista, comporta um percentual de área florestal um pouco maior, mas fortemente alterada, sendo conseqüência direta do ciclo de exploração da árvore Araucaria angustifolia (Pinheiro do Paraná) ocorrido principalmente em meados do século passado. Nesse contexto, litoral paranaense pode ser considerado uma situação particular no processo de ocupação das terras. Apesar de ter sido a primeira região a receber os imigrantes europeus no estado, a baixa fertilidade dos solos da planície litorânea não favoreceu o estabelecimento de atividades agrícolas, levando ao abandono das terras e ao declínio de alguns núcleos urbanos, tal como ocorreu, por exemplo, com a localidade de Porto de Cima. Na região da Serra do Mar Paranaense, devido ao seu característico relevo íngreme, prevaleceu a cobertura vegetal original com poucas alterações. Atualmente essa região, no qual a APA de Guaratuba está inserida, é a que abriga as maiores área com remanescentes florestais do Paraná.

A partir da observação do mapa de uso e ocupação (figura 4) pode-se perceber que esta unidade de conservação possui a maior parte de sua área recoberta por florestas pouco alteradas ou em estágio de sucessão vegetal avançado, cuja proporção de cobertura do solo equivale a mais de $60 \%$ da área total (quadro1). Faz parte ainda desse mosaico natural áreas com formas vegetacionais de formações pioneiras. As áreas compreendidas como antropizadas com atividades agropecuárias, silvicultura e com urbanização, representam pouco mais que $5 \%$ do total, as áreas em estágio de recuperação com floresta em estágio inicial de sucessão representam 10,97\% e em estágio intermediário de sucessão 12,46 da área total (quadro1). 
QUADRO 1 - USO E COBERTURA DO SOLO NA APA DE GUARATUBA

\begin{tabular}{|c|c|c|c|}
\hline \multicolumn{2}{|c|}{ Classes de uso e cobertura do solo } & Área $\left(\mathbf{k m}^{2}\right)$ & Proporção (\%) \\
\hline \multirow{7}{*}{$\begin{array}{l}\text { Floresta em estágio } \\
\text { avançado de sucessão } \\
\text { vegetal (pouco alterada } \\
\text { ou primária) }\end{array}$} & \multirow{7}{*}{$\begin{array}{l}\text { Floresta Ombrófila Densa Alto-Montana } \\
\text { Floresta Ombrófila Densa Montana } \\
\text { Floresta Ombrófila Densa Submontana } \\
\text { Floresta Ombrófila Densa Aluvial } \\
\text { Floresta Ombrófila Densa das Terras Baixas } \\
\text { Floresta Ombrófila Mista Montana } \\
\text { Floresta Ombrófila Mista Aluvial } \\
\end{array}$} & 13,24 & 0,66 \\
\hline & & 414,94 & 20,79 \\
\hline & & 651,52 & 33,06 \\
\hline & & 51,71 & 2,59 \\
\hline & & 85,44 & 4,28 \\
\hline & & 27,20 & 1,32 \\
\hline & & 0,11 & 0,01 \\
\hline \multicolumn{2}{|c|}{ Floresta em estágio intermediário de sucessão vegetal } & 248,73 & 12,46 \\
\hline \multicolumn{2}{|c|}{ Floresta em estágio inicial de sucessão vegetal } & 218,98 & 10,97 \\
\hline \multicolumn{2}{|c|}{ Refúgios vegetacionais montanos e altomontanos } & 0,28 & 0,02 \\
\hline \multirow{5}{*}{ Formações pioneiras } & \multirow{5}{*}{$\begin{array}{l}\text { Com influência fluvial de porte arbóreo } \\
\text { Com influência fluvial de porte } \\
\text { herbácea/arbustiva } \\
\text { Com influência fluviomarinha de porte arbórea } \\
\text { Com influência fluviomarinha de porte herbácea/ } \\
\text { arbustiva } \\
\text { Com influência marinha arbóreo }\end{array}$} & 24,50 & 1,23 \\
\hline & & 11,29 & 0,56 \\
\hline & & 48,21 & 2,41 \\
\hline & & 15,05 & 0,75 \\
\hline & & 6,38 & 0,32 \\
\hline \multirow[t]{3}{*}{ Áreas antropizadas } & $\begin{array}{l}\text { Agropecuária (cultivo agrícola de banana, arroz, } \\
\text { etc; pecuária com pequenos rebanhos de gado de } \\
\text { corte e leite e búfalos }\end{array}$ & 61,11 & 3,06 \\
\hline & \begin{tabular}{|l|} 
Silvicultura de Pinus spp. \\
\end{tabular} & 47,35 & 2,37 \\
\hline & Urbanização & 1,31 & 0,06 \\
\hline \multicolumn{2}{|l|}{ Corpos d'água } & 61,56 & 3,08 \\
\hline
\end{tabular}


FIGURA 4 - MAPA DE USO E COBERTURA DO SOLO DA APA DE GUARATUBA

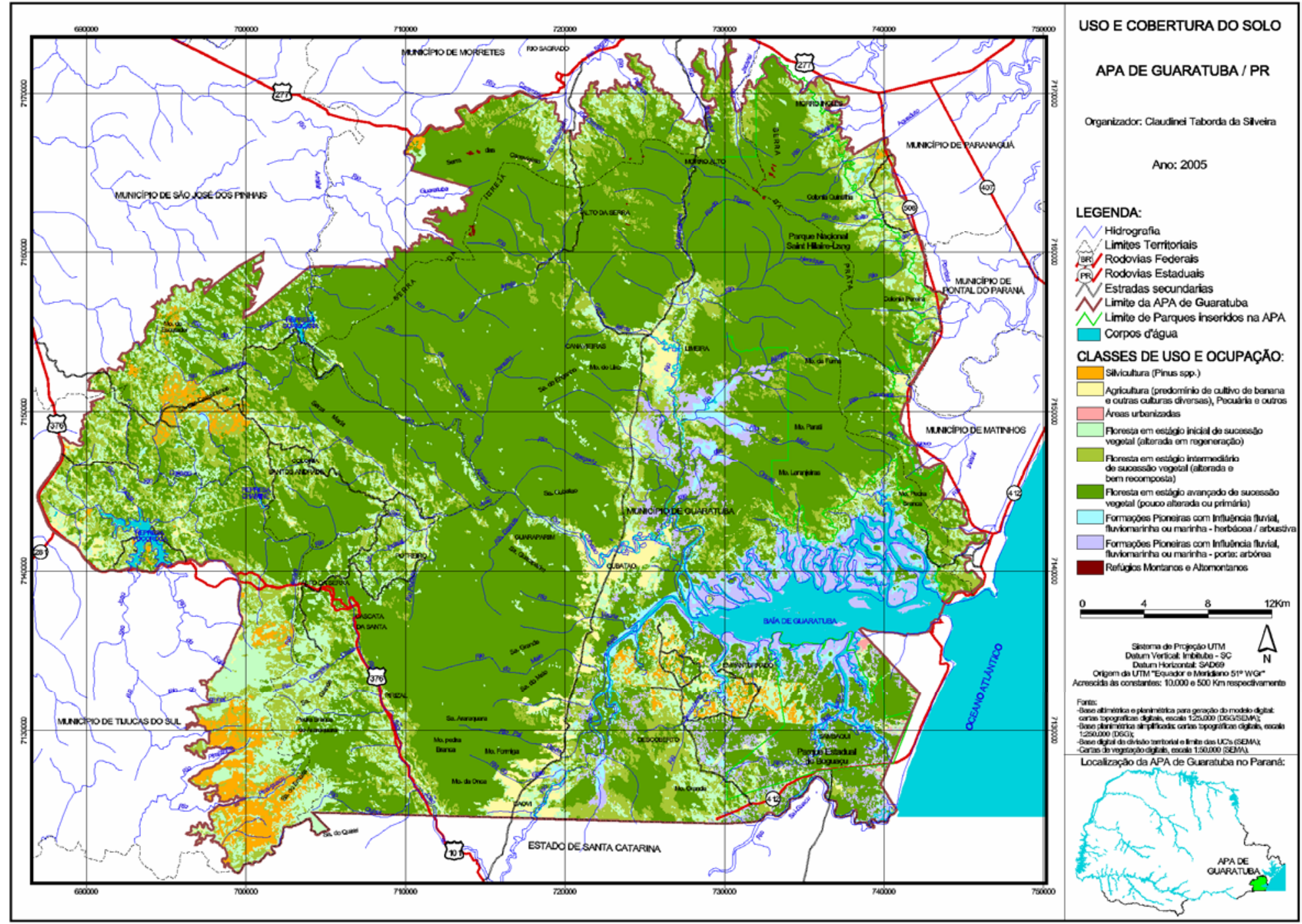




\section{MANESCENTES DA FLORESTA ATLÂNTICA}

Para o desenvolvimento desse trabalho a terminologia adotada para a classificação da vegetação na área de estudo segue a proposta do IBGE (1992), utilizando-se como referência principal as informações mapeadas nas cartas de vegetação para o programa Pró-Atlântica e lançada pela SEMA (2002a), e informações do Atlas de Vegetação do Estado do Paraná, elaborado pela SEMA (2002b).

As regiões fitogeográficas que compõe o cenário na região da APA de Guaratuba são as Formações Pioneiras e Floresta Ombrófila Densa, nas porções da planície litorânea; a Floresta Ombrófila Densa e os Refúgios Montanos e Altomontanos, localizados na Serra do Mar e a Floresta Ombrófila Mista e Densa, bem como suas zonas de ecótono, inseridos nas porções de planalto.

As regiões de domínio da Floresta Ombrófila Densa das áreas costeiras, denominada também de Floresta Pluvial Tropical Atlântica, Mata Pluvial Tropical da Serra do Mar ou Floresta Atlântica, foi muito devastada no ultimo século restando poucos remanescentes, localizando-se os mais expressivos nas regiões sudeste e sul do Brasil. Na APA de Guaratuba esse domínio florestal possui uma expressiva área (figura 5). Esta tipologia fitogeográfica ocorre associada ao conjunto da Serra do Mar e paralela à linha de costa atlântica nas planícies arenosas de origem quaternária, onde a serra está mais afastada do mar. As formações fitoecológicas da Floresta Ombrófila Densa, de ocorrência na área de estudo são:

Floresta Ombrófila Densa Aluvial, distribuídas sobre as planícies aluviais dos principais rios que compõe a bacia hidrográfica atlântica, sujeitas em muitos casos a determinados graus de hidromorfia. Sua ocorrência não tem relação direta com cotas altimétricas, mas sim com a existência de planícies aluviais ao longo dos grandes rios. $\mathrm{Na}$ área de estudo estão localizadas junto aos rios São João e Cubatãozinho, sendo ambos importantes rios e, também, em alguns de seus afluentes menores, sendo os rios Vitória, Alegre, do Meio, das Onças e Rasgado;

Floresta Ombrófila Densa de Terras Baixas, que estão restritas na área de estudo às planícies costeiras de origem quaternária, apresentando-se em locais situados entre $5 \mathrm{e}$ 30 metros de altitude, com algumas características marcantes, como a ocorrência sobre solos pouco desenvolvidos e a alta suscetibilidade à inundações, decorrentes do aumento de nível do lençol freático durante os períodos mais chuvosos, fatores que determinam uma composição florística e estrutural bastante típica. Na APA estão situadas predominantemente na porção sul da Baía de Guaratuba, ao longo dos rios Boguaçu, Descoberto e Saí-Guaçu. Podem ser separadas em duas sub-formações com algumas diferenciações principalmente florísticas, as situadas em solos hidromórficos e as de ocorrência em solos não-hidromórficos;

Floresta Ombrófila Densa Submontana, estão distribuídas sobre o início das encostas da Serra do Mar e no vale do rio Ribeira. Estão situadas entre 30 e 400 metros, no entanto, ocorre também em porções da planície litorânea a partir de 10 metros, sobre leques coluviais de origem continental. Geralmente essas formações estão sobre solos das classes dos Cambissolos. Na APA é a formação vegetacional de extensão mais representativa, abrangendo grande parte das vertentes da Serra do Mar, nos terços inferiores e intermediários. É caracterizada por sua diversidade de espécies arbóreas;

Floresta Ombrófila Densa Montana, tem ocorrência subsequente a formação Submontana, estando separadas por parâmetros altimétricos, sendo a formação Montana situada em altitudes de 400 a 1.000 metros, um limite altitudinal bastante subjetivo. 
Desse modo, fisionômica e estruturalmente as formações Montana e Submontana são muito semelhantes. Na área de estudo a formação Montana está distribuídas sobre a porção intermediária e superior das vertentes da Serra do Mar, abrangendo expressiva área e diversos cumes de serras, tais como das serras Canavieiras, Araraquara, Maria, do Engenho, entre outras. Esta formação caracteriza-se ainda pela abundância de pteridófitas (xaxins) ocorrentes no sub-bosque;

Floresta Ombrófila Densa Alto-Montana, situada nas porções mais elevadas da Serra do Mar, acima dos 1.000 metros, muitas vezes associadas aos refúgios vegetacionais campestres e rupestres - Campos de altitude - das cimeiras das serras. A formação Ombrófila Densa de Alto-Montana é denominado também de "Matas Nebulares", sendo constituída por associações arbóreas simplificadas e de porte reduzido variando entre 3 e 7 metros de altura, regidas por condicionantes climáticas e pedológicas mais restritivas como baixas temperaturas, ventos fortes e constantes, elevada nebulosidade, intensa radiação luminosa e solos progressivamente mais rasos e de menor fertilidade, que dificultam o desenvolvimento de vegetação de porte arbóreo. Na APA de Guaratuba situa-se em algumas cristas dos cumes mais elevados das serras da Igreja, Sagrado, Embira e da Prata..

As regiões de domínio da Floresta Ombrófila Mista, também conhecida como Floresta de Pinheiros, Pinheirais, Zona dos Pinhais, Matas de Araucária ou Florestas com Araucária, esta zona fitogeográfica está inserida a uma região de clima pluvial subtropical, ocorrendo abaixo do Trópico de Capricórnio, predominantemente nos estados do sul: Paraná, Santa Catarina e Rio Grande do Sul. Esse domínio florestal está sub-dividido em quatro formações distintas, de acordo com critérios altitudinais e fisionômicos: Floresta Ombrófila Mista Aluvial, Submontana, Montana e Alto-Montana. No entanto, apenas uma dessas formações aparece na APA de Guaratura, a formação Montana que ocupa as regiões planálticas, na faixa de ocorrência altitudinal entre 400 e 1.000 metros. Está situada nas vertentes da porção ocidental da Serra do Mar (figura 5), nas proximidades da represa Voçoroca, estando inserida sobre os compartimentos de planalto, que fazem parte do início do Primeiro Planalto Paranaense. É fortemente caracterizado pela espécie Araucaria angustifolia (pinheiro do Paraná), cujos indivíduos alcançam em média 25 metros de altura.

A expressão Formações Pioneiras é utilizada para denominar um tipo de cobertura vegetal formado por espécies colonizadoras de ambientes novos, ou seja, áreas subtraídas naturalmente de outros ecossistemas ou surgidas em função da atuação recente de mecanismos morfodinâmicos e pedogenéticos. Estas espécies ditas pioneiras assumem grande importância na preparação do meio à instalação subseqüente de espécies mais exigentes ou menos adaptadas a condições de instabilidade ambiental. As Formações Pioneiras são, portanto, associações vegetais ainda em fase de instalação dependentes de fatores ecológicos instáveis. Estas formações também recebem a designação de vegetação edáfica ou comunidades edáficas de primeira ocupação já que sua existência está diretamente relacionada às condicionantes edáficas. Freqüentemente encontram-se sob um regime de sucessão primária. De acordo com o tipo de ambiente em que se desenvolvem, as Formações Pioneiras são classificadas em três grupos (figura 5):

Formações Pioneiras de Influência Marinha são representadas pela vegetação herbácea de dunas e pela vegetação de restinga, distribuídas na Planície Litorânea por terrenos arenosos do Quaternário recente, geralmente com algum teor salino, sujeitos à intensa radiação solar e acentuada ação eólica. Em locais mais afastados da atual linha de praia, a vegetação apresenta-se mais desenvolvida e já estabilizada, caracterizando as restingas 
arbustivas que atingem alturas de poucos metros. Em solos mais desenvolvidos ocorrem as restingas arbóreas que chegam a atingir até 10 ou 12 metros de altura, ocorrendo preferencialmente nas partes altas dos cordões litorâneos, com solos de drenagem rápida e lençol freático mais profundo. A vegetação de restinga é uma das precursoras da Floresta Ombrófila Densa de Terras Baixas, muitas vezes se observando um gradiente de desenvolvimento da praia para o interior da planície. O limite entre ambos os tipos é conceitual, no entanto alguns autores aceitam como tal a linha de contato entre terrenos holocênicos e pleistocênicos. Assim sendo, os primeiros comportam vegetação de restinga, enquanto os últimos são detentores de Floresta Ombrófila Densa das Terras Baixas. $\mathrm{Na}$ área de estudo as formações de influência marinha foram cartografadas em áreas esparsas e distribuídas na porção de planície ao sul da Baía de Guaratuba, sendo pouco representativa em termos de extensão superficial;

Formações Pioneiras de Influência Fluvio-marinha, mais conhecida como Manguezais, desenvolvem-se na região litorânea em desembocaduras de rios e nas orlas das baías, ocupando solos lodosos de elevado teor salino e baixa oxigenação. $\mathrm{Na}$ área de estudo essa formação aparece bastante representativa, estando circundando as margens da Baía de Guaratuba e na extensão dos rios Boguaçu e descoberto e na foz do rio São João;

Formações Pioneiras de Influência Fluvial apresentam-se sob duas formas: herbáceoarbustiva (várzeas e taboais) e arbórea (caxetais, entre outros), desenvolvendo-se sobre as planícies aluviais dos inúmeros rios presentes no Estado do Paraná. Trata-se de áreas aplainadas formadas pela deposição de material carreado principalmente durante as grandes cheias dos rios. Estas regiões apresentam geralmente grande fertilidade, encontrando-se, no entanto, periódica ou permanentemente encharcadas. Na APA de Guaratuba essas formações ocorrem principalmente na planície litorânea, situada em maior extensão na região da Lagoa do Parado.

As áreas de Refúgios Vegetacionais constituem a vegetação das cimeiras das serras, situadas acima do limite da Floresta Ombrófila Densa Alto-Montana ou a ela entre meada. Abrange formações campestres geralmente acima de 1.200 a 1.300 metros de altitude, os campos de altitude, e a vegetação dos afloramentos e paredões rochosos dos topos das montanhas, denominada vegetação rupestre.

FIGURA 5 - REGIÕES FITOGEOGRÁFICAS

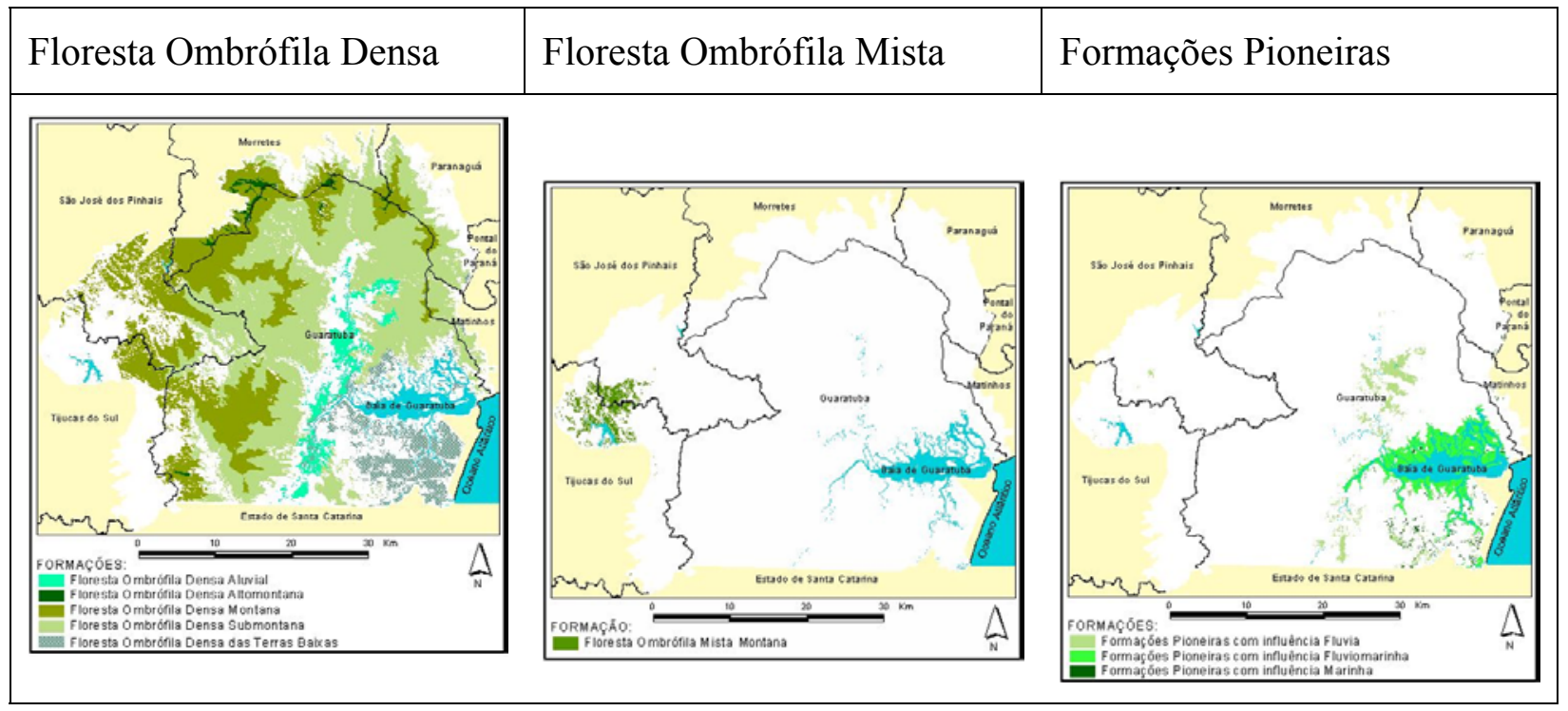




\section{INFLUÊNCIAS ANTRÓPICAS}

O sistema agrícola, que representa a principal atividade na APA de Guaratuba, possui um caráter bastante heterogêneo coexistindo tanto a agricultura tradicional como a comercial, em meio a um quadro de complexidades sociais que são agravadas pela pobreza das populações locais, degradação ambiental, apropriação desigual dos recursos naturais, inaplicabilidade de um plano de gestão conciso, pouca eficiência as políticas publicas e falta de infra-estrutura para o desenvolvimento social e sustentável.

A agricultura comercial tem como principal produto a banana, sendo cultivada principalmente ao longo da Estrada Limeira-Cubatão, em maior parte nas áreas da planície, também nas porções intermediárias das vertentes dos morros e nas porções inferiores das vertentes das serras (figura 6: fotos 1 e 2).

Quando localizadas na planície as áreas com cultivo de bananas possuem um sistema de drenagem para desencharcar o solo através de valas, que acompanham as estradas de acessos dentre o meio dos bananais (figura 6: foto 3). Geralmente os proprietários dessas áreas não respeitam os limites designados na legislação ambiental para as Áreas de Preservação Permanente (figura 6: foto 4), principalmente na mata ciliar dos rios, levando ao solapamento de suas margens (figura 6: foto 5), a lixiviação e entulhamento dos canais, também provocando o assoreamento na baía de Guaratuba, causada pela aceleração do porte de sedimentos transportados. Uma outra degradação que é conseqüência desse tipo de cultivo é a contaminação das águas fluviais, uma vez que são utilizados agrotóxicos nos bananais, inclusive em alguns casos sendo aplicado com uso de pequenos avião, o que resulta na maior dispersão desses produtos nos cursos d'água.

Os cultivos de bananas situados nas vertentes íngremes nos morros ou serras (figura 6: foto 6) propiciam aumento da erosão laminar, uma vez que dentre os bananais não há vegetação arbustiva ou herbácea, que favoreçam a retenção de sedimentos e infiltração da água. Também nessas encostas ocorre a propensão para deslizamentos, uma vez que o peso da vegetação sobre as vertentes é substituído pelos pesos dos pés de bananais, no entanto o efeito de atirantamento das raízes que havia com a cobertura vegetal deixa de existir quando essa é substituída por esses cultivos, pois a vegetação natural cria uma verdadeira teia com suas raízes, fazendo que uma sustente a outra.

Embora haja uma relação natural entre deslizamentos em escostas e períodos de alta pluviosidade, desmatamentos e outras formas de interferência antrópica agravam o desencadeamento de tais fenômenos. Embora seja de difícil avaliação todas as possíveis formas de influência da cobertura vegetal natural na estabilidade das vertentes, alguns aspectos importantes podem ser investigados e integrados na análise clássica da estabilidade de vertentes: resistência do sistema solo-raiz, peso da cobertura vegetal, efeito de atirantamento das raízes e força de arrasto do vento atuando nas copas das árvores.

Outra maneira em que a cobertura vegetal atua como agente de equilíbrio da paisagem é protegendo o solo contra o impacto direto das gotas de chuva na superfície, pois essa ação ocasiona a desagregação das partículas e compactação do solo; diminuição da capacidade de infiltração da água levando ao aumento do escoamento superficial; morte dos microorganismos biológicos que irá influenciar na porosidade e fertilidade do solo. Portanto capacidade de proteção exercida pela cobertura vegetal no solo está diretamente relacionada com a dinâmica dos processos morfogenéticos atuantes.

Ainda que em muito menor extensão na APA o cultivo de arroz é uma das culturas comerciais praticadas. Localiza-se na planície, distribuídas pontualmente. O preparo para o cultivo de arrozais se dá pelo encharcamento do solo, inundando-o (figura 6: foto 7), para 
isso é necessária a canalização da água de rios. O principal impacto desse cultivo é a contaminação das águas dos lençóis freáticos, uma vez que são aplicados agrotóxicos nos arrozais e esses terrenos estão alagados (figura 6: foto 8).

$\mathrm{Na}$ agricultura tradicional ocorre a prática de cultivos em pequenas áreas para fins de consumo próprio e subsistência familiar. Geralmente esses se localizam próximo das residências e são praticados de modo artesanal. Os principais produtos desse cárater encontrados na APA são pequenas plantações de mandioca (figura 6: foto 9) e milho, estando situados indiscriminadamente em todas as regiões onde há propriedades rurais.

Além dos produtos agrícolas já mencionados foi identificado no roteiro de campo o cultivo de palmeira real e gengibre, ambos ocupando áreas pouco significativas, no entanto sendo uma atividade crescente para fins comerciais. O gengibre é praticado na planície litorânea, ao sul da APA, nas proximidades da Estrada Cubatão-Limeira e PR 412. Segundo depoimento do proprietário de área ocupada por esse cultivo, a comercialização do produto é para fins de exportação. A palmeira real também é uma cultura em ascensão, uma vez que vem substituir o consumo do palmito jussara, no trabalho de campo realizado pela UC foi identificado sua presença em propriedades rurais situadas na porção norte da APA, na extensão da Estrada Cubatão-Limeira e Estrada Rio Sagrado.

A pecuária praticada na extensão da APA se constitui atualmente de pequenos rebanhos. A fazenda Estrela, situada na Estrada Cubatão-Limeira, na comunidade Cubatão, possui criação de búfalos (figura 6: foto 10), no entanto o rebanho atual menor do que no passado, segundo afirmado pelo administrador da fazenda em conversa tida na visita à essa propriedade no trabalho de campo, a bubalinocultura será extinta da fazenda tendo atualmente cerca de 600 animais ali sendo criados, e serão substituídos pela criação de gado da raça Nelori, estimando possuir 5.000 reses. A bubalinocultura está na porção de planície em terrenos encharcados e alagadiços. Os principais impactos estão vinculados com o pisoteamento dos búfalos nas margens dos canais levando ao solapamento pelo tráfego desses animais de grande porte nessas áreas, também a compactação e desestruturação do solo.

A criação de gado é presente em diversas propriedades rurais na APA, sendo de rebanhos muito pequenos, por vezes apenas algumas reses de engorda ou leite. Nas propriedades com acesso pelas estradas vicinais que partem da BR 277 e PR 412, ao norte e nordeste da área de estudo (figura 6: fotos 11), e nas vicinais de acesso a partir da rodovia BR 376 à oeste.

A silvicultura de Pinus spp. é um dos tipos de antropização com grande representatividade espacial na APA de Guaratuba. Esses reflorestamentos estão situados significativamente na porção sudoeste, sobre o corpo granítico morro redondo na Serra do Mar, em uma área extensa, cuja topografia do terreno é de declividade acentuada. Outra porção com usos do solo ocupado por silvicultura está localizada à oeste na UC, na unidade fisiográfica do Primeiro Planalto Paranaense, nas proximidades da Colônia Castelhanos, extendendo-se nas margens das estradas vicinais (figura 6: foto 12). De modo menos denso a silvicultura está presente na Planície Litorânea, ao sul da baía de Guaratuba, nas proximidades das comunidades Descoberto, Riozinho e Estaleiro.

Quanto à exploração mineral, conforme foi avaliado e constatado nos levantamentos elaborados realizados pela empresa Minerais do Paraná S/A - MINEROPAR (2001 e 2002), a maioria das jazidas situadas na APA de Guaratuba se concentra em três regiões principais: rodovia Alexandra-Matinhos, no município de Matinhos; estrada de GuaratubaGaruva, nas proximidades da localidade de Coroados e limite com o Estado de Santa Catarina e nas proximidades da rodovia BR 376, município de São José dos Pinhais. 
Atualmente a atividade de mineração de maior interesse econômico na APA é a exploração de materiais para a construção civil e manutenção de estradas.

A extração de areia é uma importante atividade econômica na área de estudo. A tendência do crescimento dessa atividade se dá pelas características físicas apresentadas pelos solos da região, que dispõe desse material, e atendem a construção civil atualmente com altas taxas de crescimento populacional, principalmente nas regiões de maior próximidade à orla litorânea. A redução dos custos com transporte para locomoção da areia de outras áreas distantes é um outro fator de agravante econômico que justifica a tendência do crescimento dessa atividade na UC. No entanto, a extração da areia nos solos podzóis, que estão situados na planície, gera degradações ambientais intensas, uma vez que a camada superficial de matéria orgânica que está sobre a base arenosa é removida, e é justamente essa camada. de material orgânico o que mantém a cobertura da Floresta Ombrófila Densa das Terras Baixas, fazendo com que a reconstituição do ambiente original seja dificultada, uma vez que a vegetação nativa não consegue desenvolver diretamente sobre a base arenosa.

Por isso, a atividade de dragagem de areia do leito dos rios (figura 6: foto 13) é uma das formas de exploração racional dessa atividade de mineração na UC, com a ressalva de que para isso devem ser seguindo todos os padrões ambientais exigidos.

As saibreiras, pedreiras e cascalheiras aparecem em locais pontuais na APA, porém causam forte impacto visual, uma vez que exige extração de toda vegetação da superfície e profundos cortes nas encostas de morros (figura 6: foto 14). Segundo consta no Plano de Manejo da APA de Guaratuba, não foi observado atividades para a recuperação ambiental das saibreiras e pedreiras paralisadas, estando muitas delas abandonadas por mais de 10 anos.

Uma das questões preocupantes na APA de Guaratuba, e que segundo SILVEIRA (2000) constitui-se numa das destacáveis pressões antrópicas nessa UC, é o avanço populacional que foi detectado por meio da elaboração de mapas temáticos de densidade e evolução demográfica. $\mathrm{O}$ avanço dos núcleos urbanos, decorrentes da especulação imobiliária, pela sua localização geográfica próximo à orla marítima, são as áreas de maior preocupação, sendo os principais focos as praias de Guaratuba, Matinhos e Caiobá, uma vez que a intensificação do turismo resulta no aumento de casas de veranistas e na necessidade de novos loteamentos. Assim a instalação de loteamentos residenciais, bem como a instalação de infra-estrutura urbana é crescente na porção sudeste da APA.

Foi constatado, por meio do levantamento de informações em trabalho de campo, que nesses novos loteamentos residenciais a população ocupante é de moradores que se fixaram nessas novas áreas pelos preços mais acessíveis, sendo eles provenientes da própria região litorânea, oriundos de Paranaguá ou de locais mais próximos, atraídos pela intenção de colocação profissional junto aos maiores adensamentos demográficos. 
Revista Eletrônica Geografar, Curitiba, v.2, n.1, p. 71-87 jan./jun. 2007 www.ser.ufpr.br/geografar

FIGURA 6 - PRANCHA COM FOTOS ILUSTRATIVAS DAS INTERVENÇÕES ANTRÓPICAS NA APA DE GUARATUBA

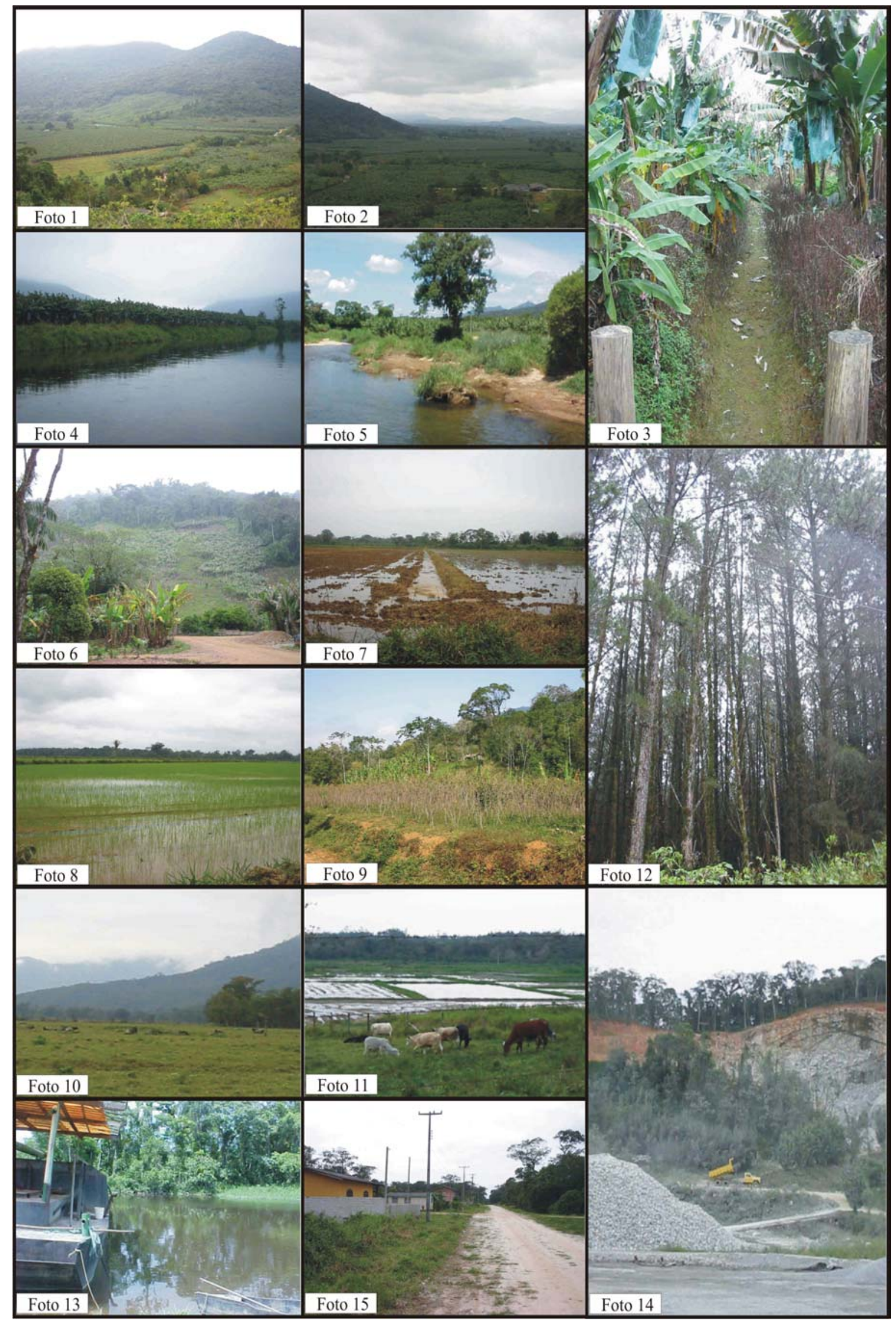


Foto1 - Cultivos de banana na porção inferior das vertentes e nas porções de planícies, fonte: Silveira (2004);

Foto 2 - Bananais na extensão da planície litorânea paranaense, fonte: Silveira (2004);

Foto 3 - Valas para drenagem e desencharcamento do solo, fonte: Silveira (2004);

Foto 4 - Cultivo de bananas nas margens dos rios sem deixar a mata ciliar e desrespeitando o limite das Áreas de Preservação Permanente, fonte: Silveira (2004);

Foto 5 - Solapamento nas margens dos rios, fonte: Silveira (2004);

Foto 6 - Cultivo de bananas em encostas íngremes, fonte: Silveira (2004);

Foto 7 - Terreno sendo preparado para o cultivo de arroz, fonte: Silveira (2004);

Foto 8 - Cultivo de arroz na planície litorânea, fonte: Silveira (2004);

Foto 9 - Cultivo de mandioca, prática de agricultura para subsistência, fonte: Silveira (2004);

Foto 10 - Criação de búfalos na área da Fazenda Estrela, fonte: Silveira (2004);

Foto 11 - Pequeno rebanho de criação de gado para corte e leite, fonte: Silveira (2004);

Foto 12 - Silvicultura de Pinus spp. (árvores de porte desenvolvido), situados na porção oeste da APA de Guaratuba, fonte: Silveira (2004);

Foto 13 - Draga instalada no rio Taquaruvu para extração de areia, fonte: Silveira \& OkaFiori (2002);

Foto 14 - Atividade de mineração, pedreira cujo produto atende a construção civil (edificação e pavimentação), fonte: Silveira (2004);

Foto 15 - Expansão urbana, avanço de loteamentos sobre a APA de Guaratuba, fonte: Silveira (2004).

\section{CONSIDERAÇÕES FINAIS}

A população residente na APA de Guaratuba, em geral rural, tem atividades diversificadas: extrativas, agrícolas, criação de animais, prestação de serviços de turismo e/ou lazer (assalariados diaristas, mensalistas e assalariados), comércio de beira de estrada de alimentos e artesanato, que geram pequenas indústrias de transformação (farinha de mandioca, passas e balas de banana, compotas e doces em pasta, mel e alambiques).

Fazer o uso correto dessa unidade de conservação é valorosa e difícil tarefa, uma vez que muitos embates se atropelam, tanto o desejo preservacionista, uma vez que por um lado se deve considerar a real necessidade de manter tal ambiente, singular e importante para todos, como também o desejo de prosperar dos residentes da região, que por sua vez buscam cada vez mais ampliar seus cultivos agrícolas e desenvolvimento econômico. 
As alternativas são de buscar compreensão e conhecer cada vez mais essa área, para que assim possam ser elaborados planos de ordenamento e gestão, ou ainda aperfeiçoando e reformulando os que estão em vigência.

\section{REFERÊNCIAS BIBLIOGRÁFICAS}

BIGARELlA, J. J.; et al. A Serra do Mar e a Porção Oriental do Estado do Paraná. Curitiba: Secretaria de Estado e Planejamento, 1978.

IBGE - INSTITUTO BRASILEIRO DE GEOGRAFIA E ESTATÍSTICA. Manual Técnico da Vegetação Brasileira. Rio de Janeiro: Fundação Instituto Brasileiro de Geografia e Estatística - DERNA. Manuais Técnicos de Geociências, n. 1, 1992.

MAACK, R. Geografia Física do Estado do Paraná. $2^{\mathrm{a}}$ ed. Rio de Janeiro: José Olympio Editora, 1981.

MINEROPAR - MINERAIS DO PARANA. Atlas Geológico do Estado do Paraná. Curitiba : MINEROPAR, 2001. 1 CD ROM.

MINEROPAR - MINERAIS DO PARANA. Relatório do Mapeamento das Cartas de Geológia do Paraná - na área de abrangência do Programa Pró-Atlântica. In: SEMA. Cartas Geologia (sul). Curitiba, 2002. 1 CD-ROM.

SEMA - SECRETARIA DE ESTADO DO MEIO AMBIENTE E RECURSOS HÍDRICOS. Cartas de Vegetação: MI 2857-2, MI 2857-4, MI 2858-1, MI 2858-2. MI 2858-3 e MI 2858-4. Curitiba. Escala 1:50.000. Material cartográfico em ambiente digital. $2002 \mathrm{a}$.

SEMA - SECRETARIA DE ESTADO DO MEIO AMBIENTE. Atlas de Vegetação do Estado do Paraná. Curitiba : SEMA 2002b. 1 CD-ROM.

SILVEIRA, C. T. APA de Guaratuba: Densidade e Evolução Demográfica. In: Seminário 2000 Ensino e Pesquisa do Setor de Ciências da Terra, 2000, Curitiba. Anais... Curitiba : UFPR, 2000. 1 CD-ROM.

SILVEIRA, C. T. Estudo das Unidades Ecodinâmicas da Paisagem na APA de Guaratuba: subsídios para o planejamento ambiental. Curitiba, 2005. Dissertação - Universidade Federal do Paraná. 